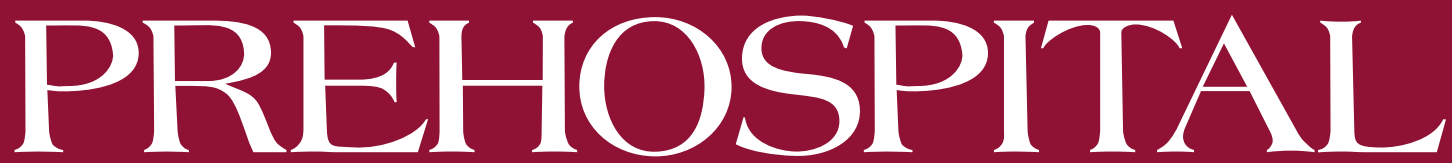
and
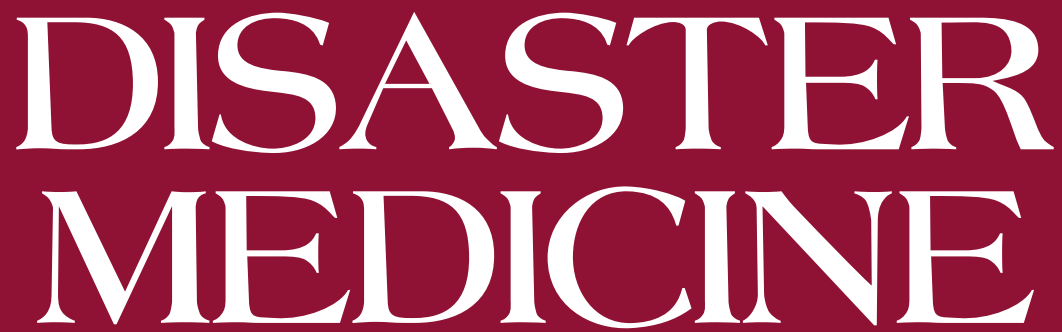

Volume 27, Number 4

August 2012

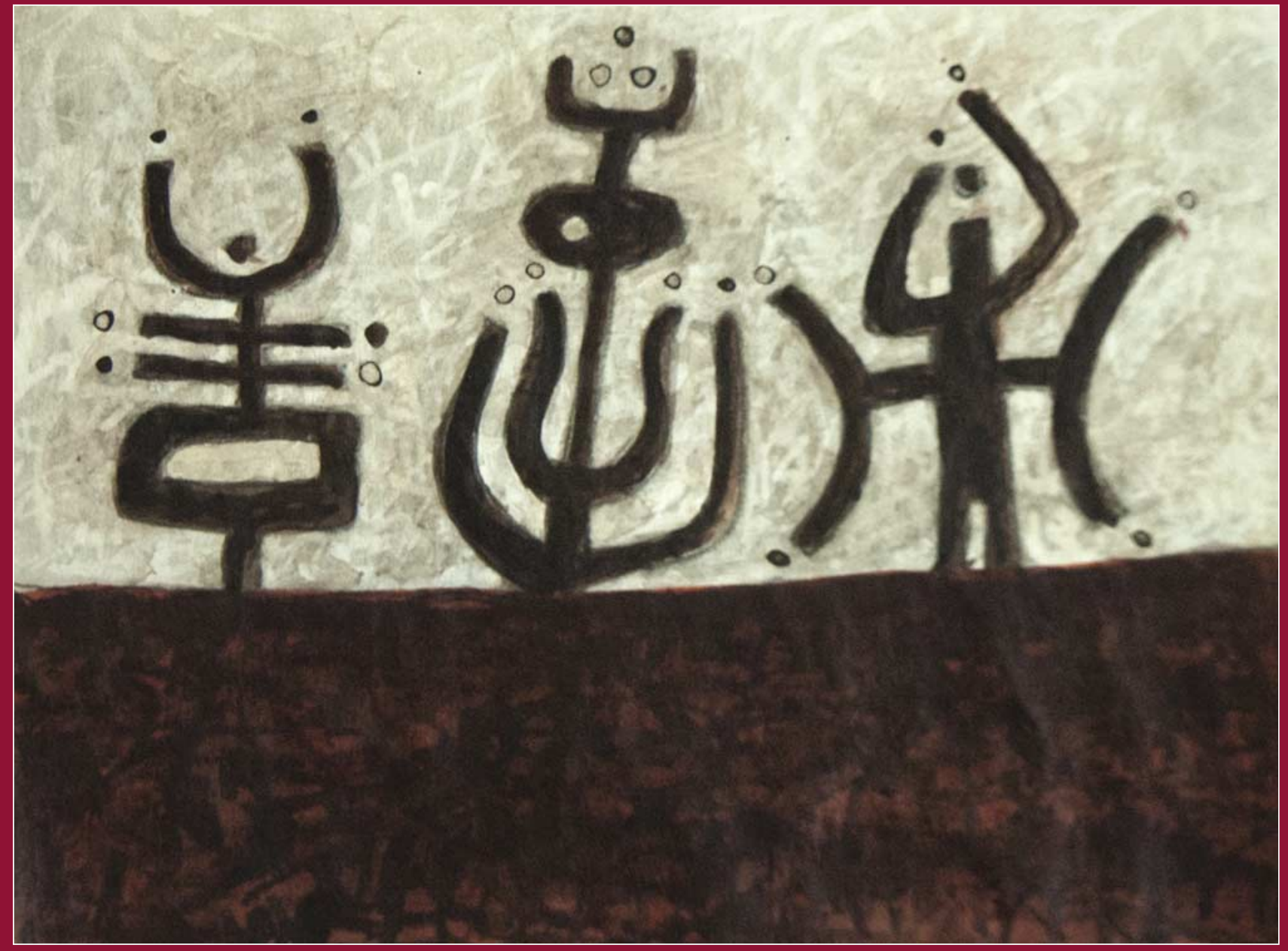

The Official Journal of the

World Association for Disaster and Emergency Medicine 


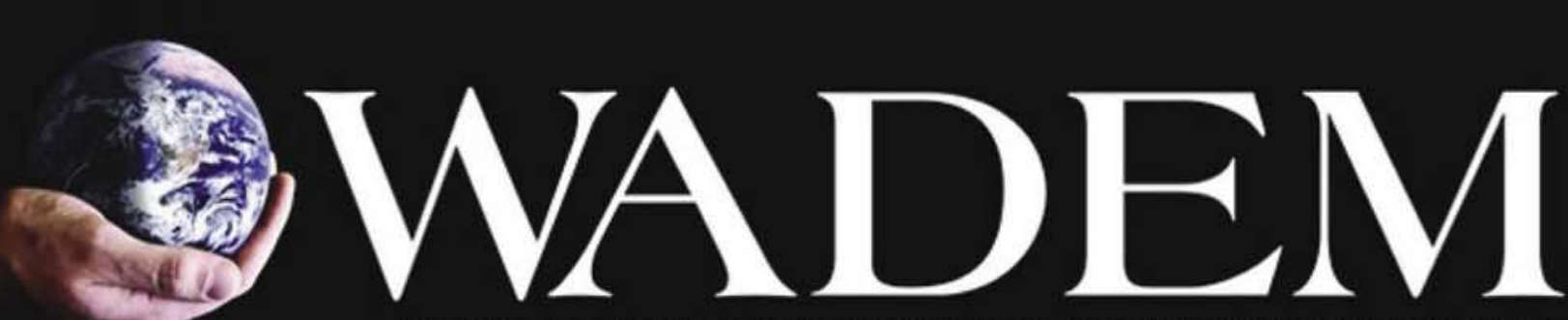

WORLD ASSOCIATION FOR DISASTER AND EMERGENCY MEDICINE

\section{SAVE THE DATE}

\section{The 4th Pan American Conference}

Topics will include:

\section{Consensus-building}

Workshops

- Disaster

Terminology

- Foreign Medical

Teams

- Accountability

- Assessments and Measurements

Discussions and Papers

- Uses of Social Media

- New Technology

- Safe Medical Facilities

- Forensics

- Psychosocial issues

- Roles of emergency, military, nursing, and medicine in disaster health

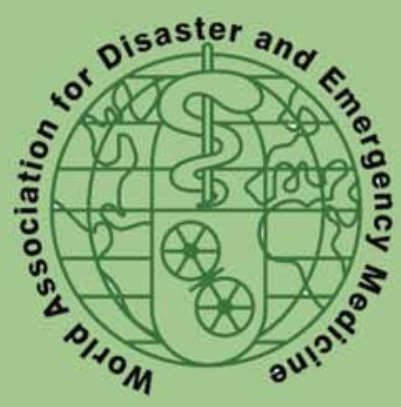

The National Conference Center

Leesburg, Virginia, USA

October $15-17,2012$

www.wadem.org

\section{Measuring Progress and Improving Preparedness in Disaster Management}

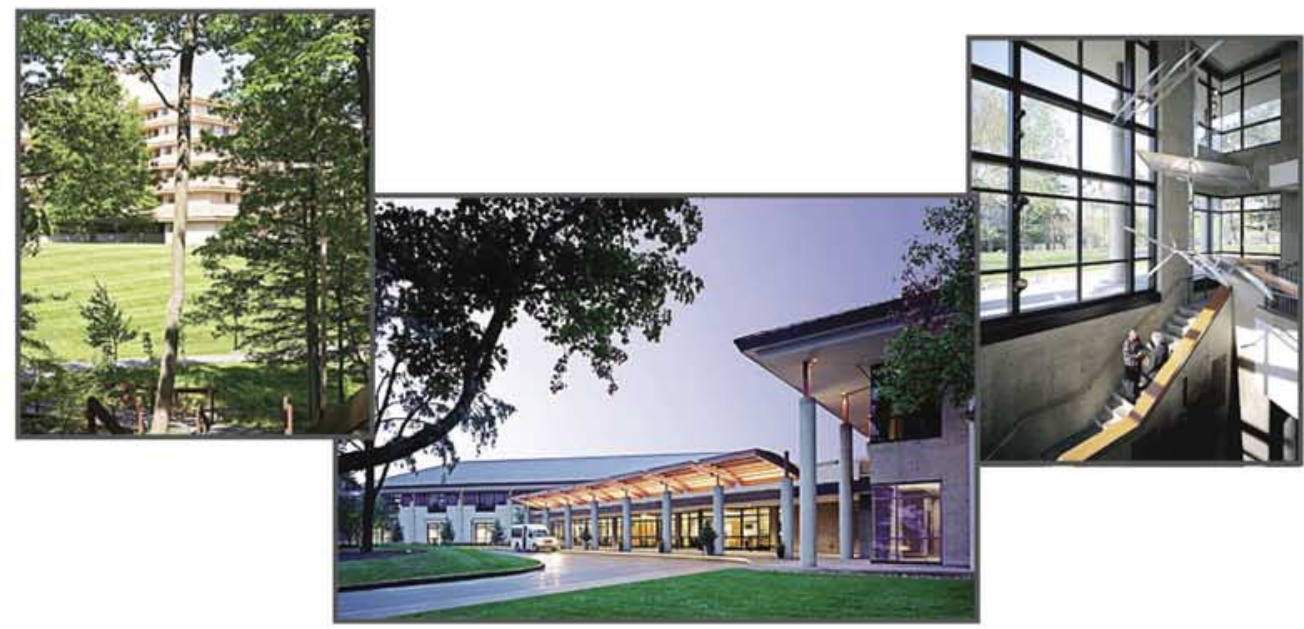

This conference will bring together individuals interested in disaster and emergency medicine/management to discuss developments in risk reduction, preparedness, and responses, and to build consensus on important related issues.

The conference will focus on risk reduction, improving preparedness, and assessing responses worldwide from prehospital care systems through post-event evaluations. There will be consensus-building workshops, debates, keynote addresses, as well as invited and free papers. Additionally, there will be several relevant pre- and postconference workshops and courses.

\section{Call for Papers}

Only 50 papers related to the above topics will be accepted.

Abstract submission opens: March 1, 2012

Deadline for submission of abstracts: May 31, 2012 


\section{Table of Contents}

\section{Editorial}

Publishing Survey Research .

Samuel J. Stratton, MD, MPH

\section{Original Research}

Independent Application of the Sacco Disaster Triage Method to Pediatric Trauma Patients ........... 306

Keith P. Cross, MD, MS, MSc; Mark X. Cicero, $M D$

CPR Skill Retention of First Aid Attendants within the Workplace

Gregory S. Anderson, PhD; Michael Gaetz, PhD; Cara Statz, BKin

Traditional and Social Media Coverage and Charitable Giving following the 2010 Earthquake in Haiti Ano Lobb, MPH; Nancy Mock, DrPH; Paul L. Hutchinson, PhD

Hospitalization Rates Among Dialysis Patients During Hurricane Katrina

David Howard, PhD; Rebecca Zhang, MS; Yijian Huang, PhD; Nancy Kutner, PhD

The Use of the Revised Trauma Score as an Entry Criterion in Traumatic Hemorrhagic Shock Studies:

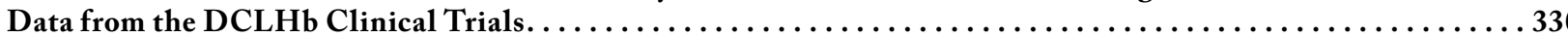

Edward P. Sloan, MD, MPH; Max Koenigsberg, MD; James M. Clark; Amol Desai, MD

Correlates of Perceived Care Comfort with an EMS Professional Having a Legal Conviction

Gary Blau, PhD; Gregory Gibson, PhD, NREMT-B

An International Expert Delphi Study to Determine Research Needs in Major Incident Management . . . . . . . 351 Kevin Mackway-Jones, FRCP, FRCS, FCEM; Simon Carley, MD, FRCS (Ed), FCEM

Psychological Consequences of Indirect Exposure to Disaster Due to the Haiti Earthquake. . . James M. Shultz, MS, PhD; Avi Besser, PhD; Fiona Kelly, PhD; Andrea Allen, PhD; Susan Schmitz, MA;

Vicky Hausmann, MS; Louis Herns Marcelin, PhD; Yuval Neria, PhD

The Impact of Stress on Paramedic Performance During Simulated Critical Events . . . . . . . . . . . . 369 Vicki R LeBlanc, PhD; Cheryl Regehr, PhD; Walter Tavares, BSc ACP; Aristathemos K. Scott RN, BScN, MEd; Russell MacDonald, MD, MPH, FRCPC; Kevin King, $C C P(F)$

Medical Priority Dispatch System Breathing Problems Protocol Key Question Combinations are

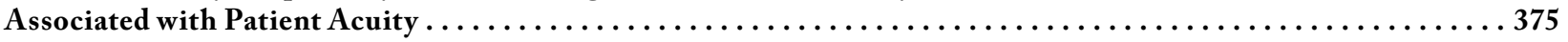
Jeff Clawson, MD; Tracey Barron, BSc; Greg Scott, MBA; Niroshan Siriwardena, MBBS, PhD; Brett Patterson; Christopher Olola, $\mathrm{PhD}$

\section{Brief Report}

In the Line of Duty: A Study of Ambulance Drivers During the 2010 Conflict in Kashmir .

Shabir Ahmed Dhar, MS; Tahir Ahmed Dar, MS; Sharief Ahmed Wani, MS; Shabid Hussain, MS; Reyaz, Ahmed Dar, MS; Zaid Ahmed Wani, MD; Shah Aazad, MBBS; Suhail Yaqoob, MS, FNB; Imtiyaz Mansoor, MD; Murtaza Fazal Ali, MS;

Muzaffar Ahmed, MS; Imran Mumtaz, MS; Idrees Azhar, MBBS 


\section{Special Report}

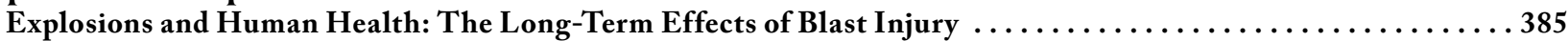

Sarah E. Finlay, FCEM; Michelle Earby, FCEM; David J. Baker, FRCA; Virginia S.G. Murray, FRCP

Evaluation of Active Mortality Surveillance System Data for Monitoring Hurricane-Related

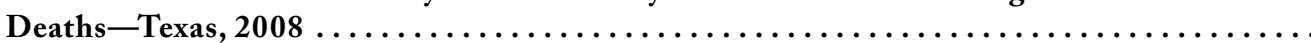

Ekta Choudhary, PhD, MPH; David F. Zane, MS; Crystal Beasley, MS; Russell Jones, MPH; Araceli Rey, RN, MPH;

Rebecca S. Noe, MN, MPH, FNP; Colleen Martin, MPH; Amy F. Wolkin, MSPH; Tesfaye M. Bayleyegn, MD 


\section{Editorial Office}

World Association for Disaster and Emergency Medicine (WADEM), Madison,

Wisconsin USA

Editor-in-Chief

Samuel J. Stratton, MD, MPH

\section{Development Editor}

Mona Johnson

Editorial Assistant

Jackson Helmer

Publisher

Cambridge University Press

32 Avenue of the Americas

New York, NY 10013-2473 USA
Prehospital and Disaster Medicine (ISSN 1049-023X) is published bimonthly in the months of February, April, June, August, October, December, by Cambridge University Press for the World Association for Disaster and Emergency Medicine. Prehospital and Disaster Medicine incorporates the Journal of the World Association for Emergency and Disaster Medicine and the Journal of Prehospital Medicine.

Editorial Information: All manuscripts must be submitted through the Journal's online submission platform, ScholarOne Manuscripts: http://mc. manuscriptcentral.com/pdm.

2012 Subscription Information: Institutions print and electronic: US $\$ 516.00$ in the USA, Canada, and Mexico; UK£313.00+VAT elsewhere. Institutions electronic only: US $\$ 375.00$ in the USA, Canada, and Mexico; UK£227.00+VAT elsewhere. Individuals print and electronic: US $\$ 153.00$ in the USA, Canada, and Mexico; UK£93.00+VAT elsewhere. Individuals electronic only: US $\$ 113.00$ in the USA, Canada, and Mexico; UK£68.00+VAT elsewhere. Single Part: US\$94.00 in the USA, Canada, and Mexico; UK£57.00+VAT elsewhere. Prices include postage and insurance. Airmail or registered mail is extra. Back volume prices are available upon request. Claims of non-receipt or damaged issues must be filed within three months of cover date.

Comprehensively indexed by the National Library of Medicine (MEDLINE), Cumulative Index to Nursing and Allied Health (CINAHL) and Health Star Cumulative Index. The database is available online via BRS, Data-Star, and DIA-LOG, and on CD-ROM through CD Plus, Compact Cambridge and Silver Platter. Abstracts and search capability available on the Internet at http://pdm.medicine.wisc.edu.

Copyright (C) 2012 by the World Association for Disaster and Emergency Medicine.

\section{Cover Artwork}

Tiny Trio (acrylic/sumi ink/paper ), by Sandra Martinez

Bio

Sandra (Hackbarth) Martinez has been focused on her primitive drawing style for 30 years. The simple and graphic nature of her work lends itself to a variety of projects, from flatweave tapestries woven by her husband, Wence Martinez, to small collections of wearable- and functional-art accessories. Sandra produces her paintings on thin paper worked with layers of washes, then framed in shadow-box format so the paper becomes a fragment, an object itself.

\section{Artist's Statement}

By September 2011, Wence and I knew we were going to New York City for the Architectural Digest Home Design Show. The first few months of winter were spent looking at what we had in stock and where we would like to fill in the gaps. We decided on the new designs, and Wence started weaving like a maniac. When I turned to my painting, I tried a new thing: scheduling. So even though I had some major irons in the fire on a daily basis, I generally stopped by mid-afternoon and went to my painting. Before I knew it, I had a cast of characters. There is a cloudiness to them, layers that you can see through, and many have a distinct line of transformation.

Now, the shadow is falling. I am helping a loved one through Alzheimer's disease. As more of my family and friends pass over - whatever that means - I'm looking at my figures a bit differently. They guard, and they beckon. They mark the way.

For more information, please go to MartinezStudio.com. 
EDITOR-IN-CHIEF

Samuel Stratton, MD, MPH

University of California-Los Angeles

Los Angeles, California, USA

\section{EMERITUS EDITOR- \\ IN-CHIEF}

Marvin L. Birnbaum, MD, PhD

University of WisconsinMadison

Madison, Wisconsin, USA

\section{DEPUTY EDITORS}

David A. Bradt, MD, MPH

Royal Melbourne Hospital

Melbourne, Australia

Geert Seynaeve, MD

Brussels, Belgium

\author{
Darren Walter \\ University Hospital of South \\ Manchester \\ Manchester, UK
}

\section{ASSOCIATE EDITORS \\ Wolfgang F. Dick, MD,PhD Center \\ San Jose, California, USA}

Mainz, Germany

\section{Kimball Maull, MD, FACS}

Department of Surgery

Hamad General Hospital

Doha, Qatar

\section{Steven Rottman, MD \\ University of California- \\ Los Angeles \\ Los Angeles, California, USA}

\section{SECTION EDITOR \\ Humanitarian Affairs \\ Frederick M. Burkle, MD, MPH, DTM \\ Senior Fellow and Scientist, \\ Harvard Humanitarian Initiative \\ Harvard University \\ Cambridge, Massachusetts, USA}

Senior Public Policy Scholar Center for Scholars

Adjunct Professor

School of Child and Youth Development Associate of the Justice Canada

\section{Paul Arbon, PhD}

School of Nursing and Midwifery

Flinders University

Adelaide, South Australia

Frank Archer, MD

Monash University

Melbourne, Australia

Jeffery Arnold, MD

Department of Emergency Medicine

Santa Clara Valley Medical

Front Command

Or-Yehuda, Israel

Joost Bierens, MD, PhD

Tareg Bey, MD

Department of Emergency Medicine Irvine, California, USA

Richard A. Bissell, PhD

University of

Maryland-Baltimore

Baltimore, Maryland, USA

Felipe Cruz-Vega, MD

Office of Social Security

Mexico City, Mexico
Woodrow Wilson International

\section{EDITORIAL BOARD \\ Carol Amaratunga, PhD \\ San Antonio, Texas, USA}

University of Victoria Research Institute of British Columbia

Yaron Bar-Dayan, MD, MHA

Israeli Defense Forces Home

Amsterdam, The Netherlands

University of California-Irvine,

\author{
Robert A. De Lorenzo, MD, \\ MSM, FACEP \\ Medical Corps \\ United States Army
}

Claude de Ville de Goyet, MD Brussels, Belgium

Judith Fisher, MD
Consultant
Washington, DC, USA

Erik S. Gaull

George Washington University

Washington, DC, USA

Michael Gunderson

President

Integral Performance Solutions

Lakeland, Florida, USA

Keith Hotlermann, MD

George Washington University

Washington, DC, USA

MarkJohnson, MPA

Retired Chief of EMS

Juneau, Alaska, USA

Mark Keim, MD

Center for Disease Control and Prevention

Atlanta, Georgia, USA

Todd J. LeDuc, EMT-P

Deputy Fire Chief Broward Sheriff Fire Rescue Ft. Lauderdale, Florida, USA

\section{Gloria Leon, PhD}

Professor of Psychology

University of Minnesota

Minneapolis, Minnesota, USA

\section{Graeme McColl}

Emergency Management Team

National Health Board

Ministry of Health

Christchurch, New Zealand

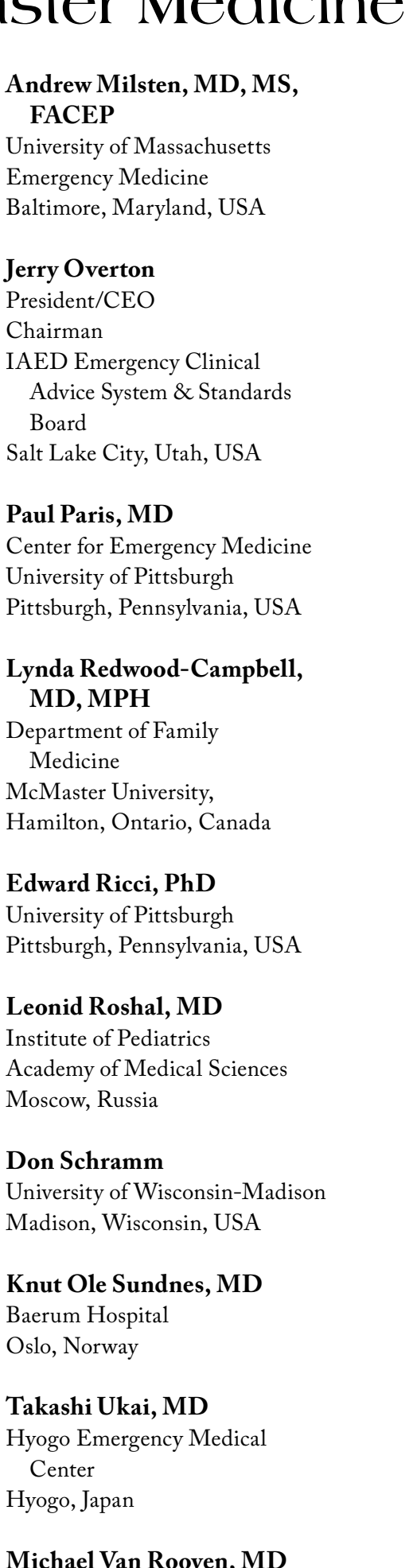

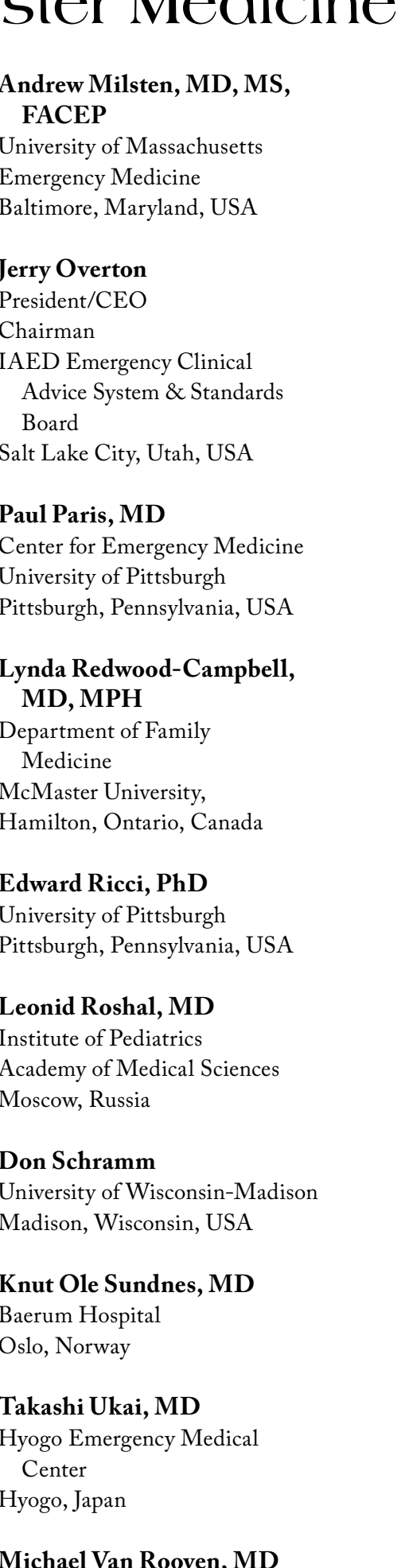

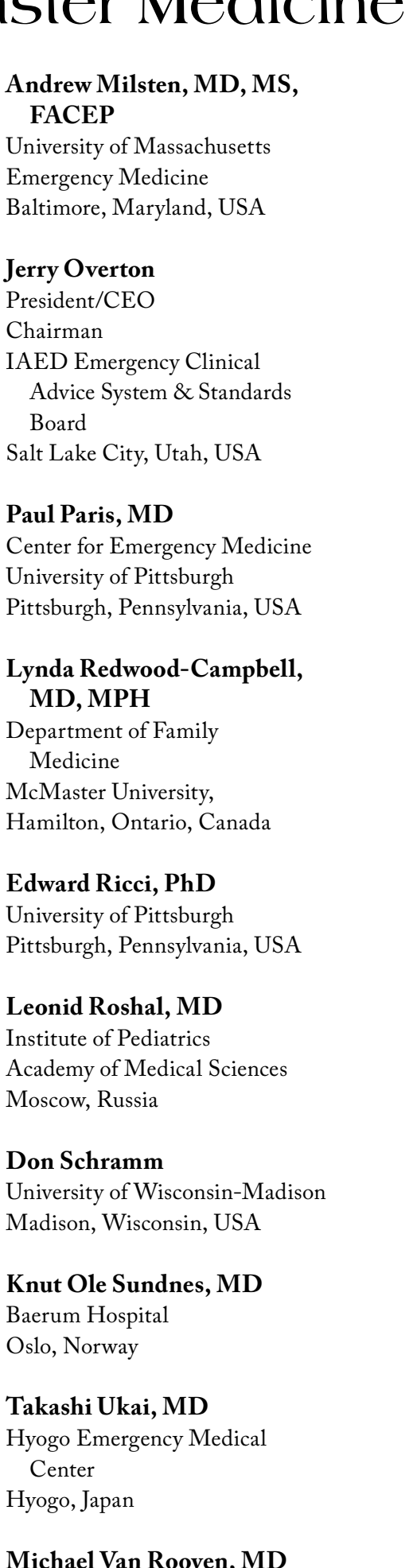

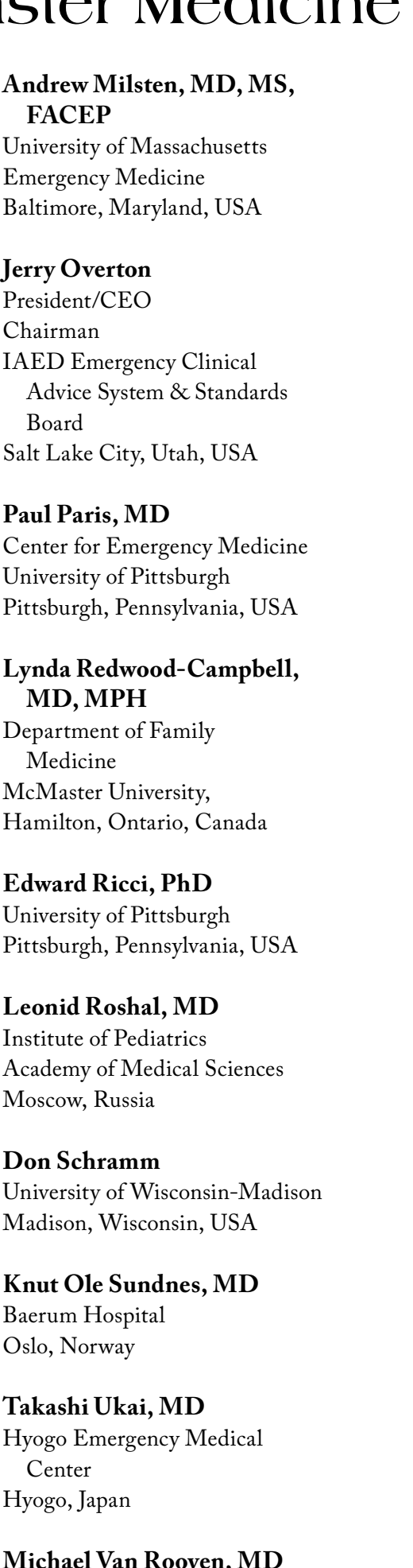

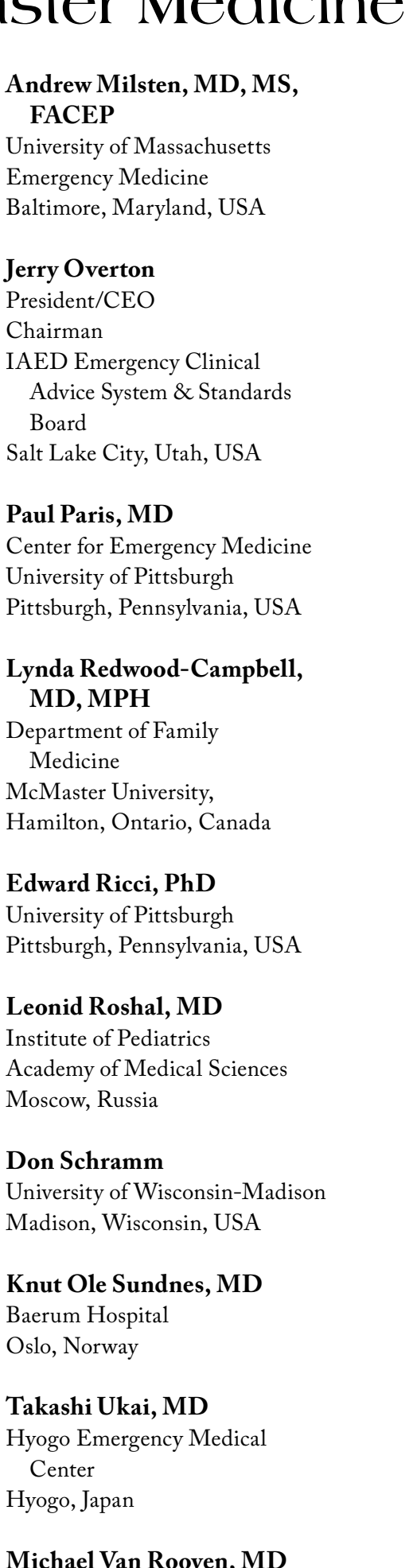

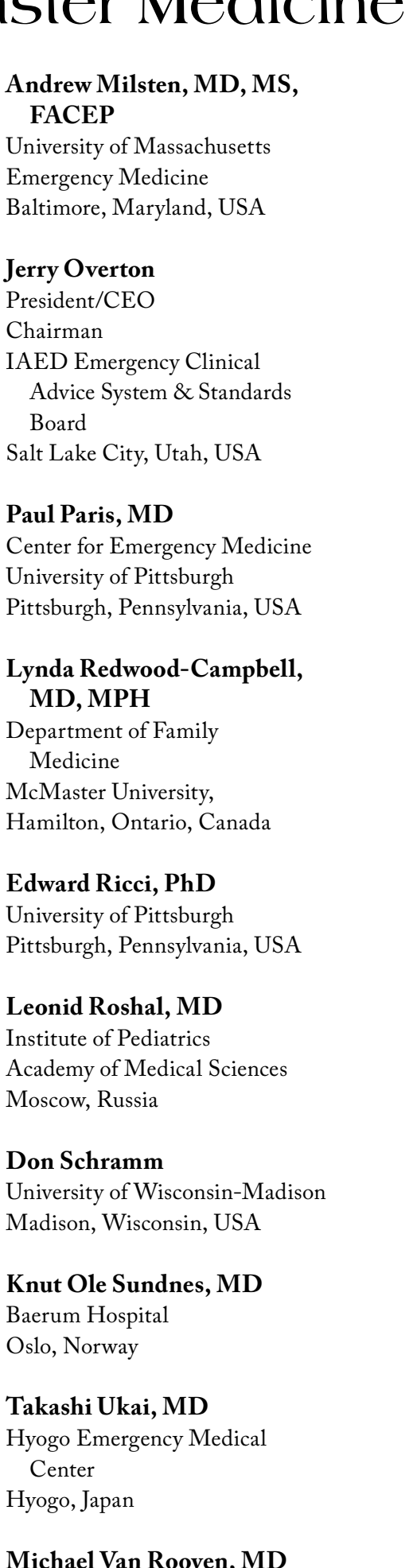

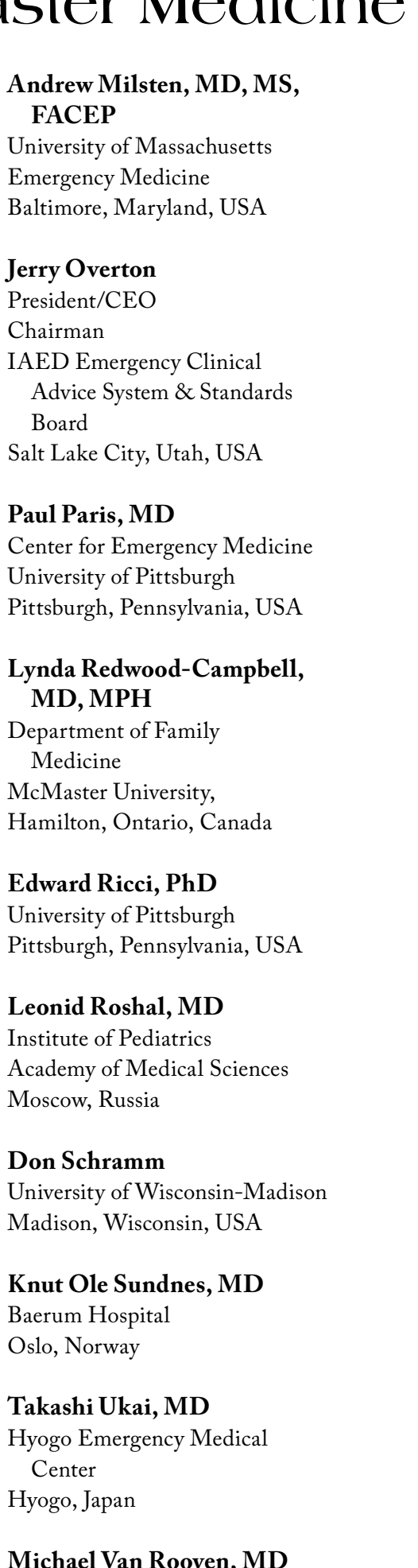

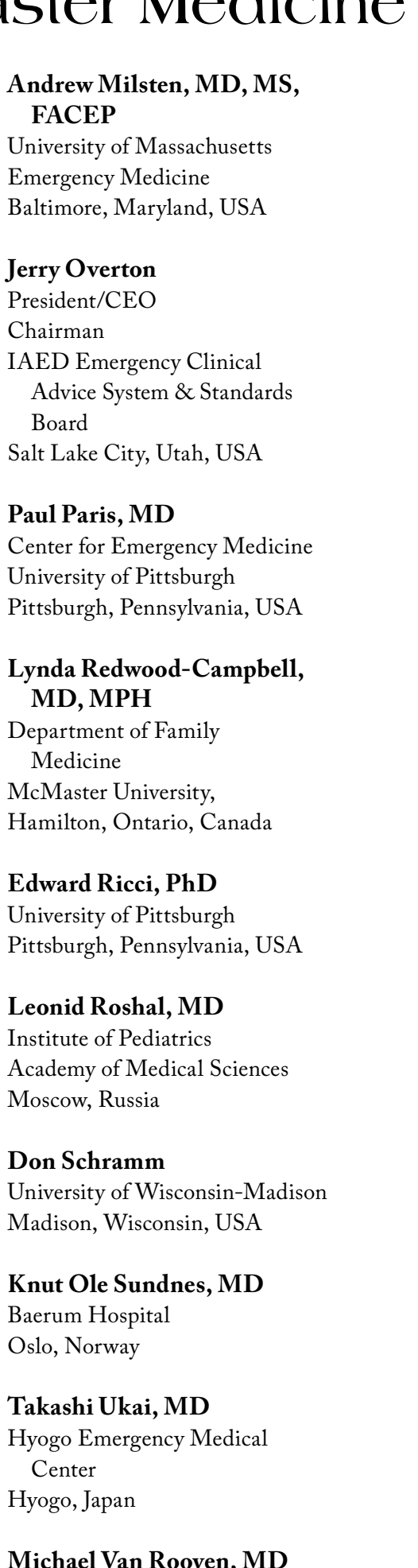

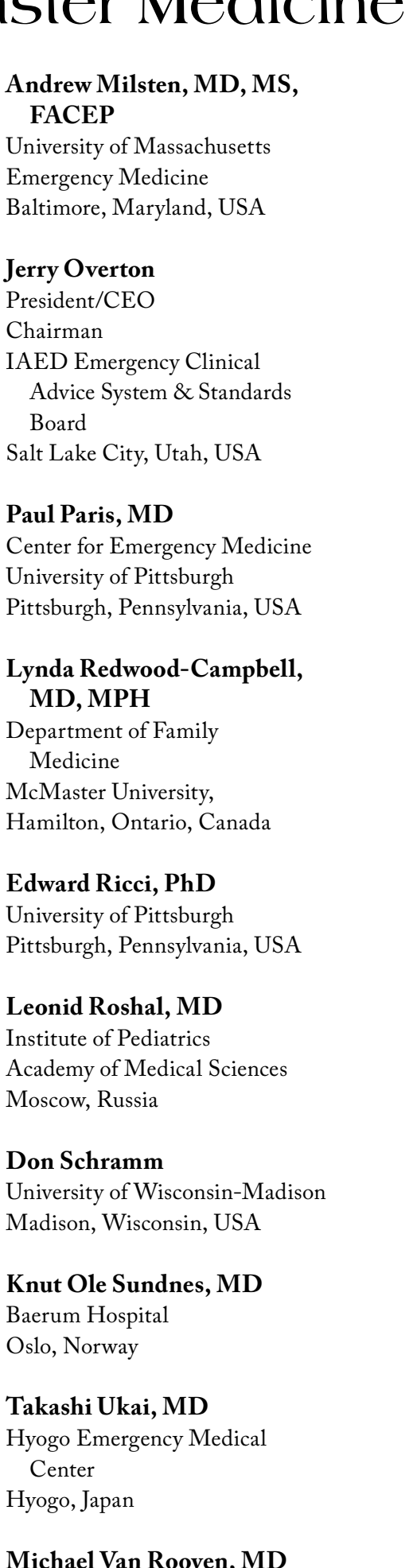

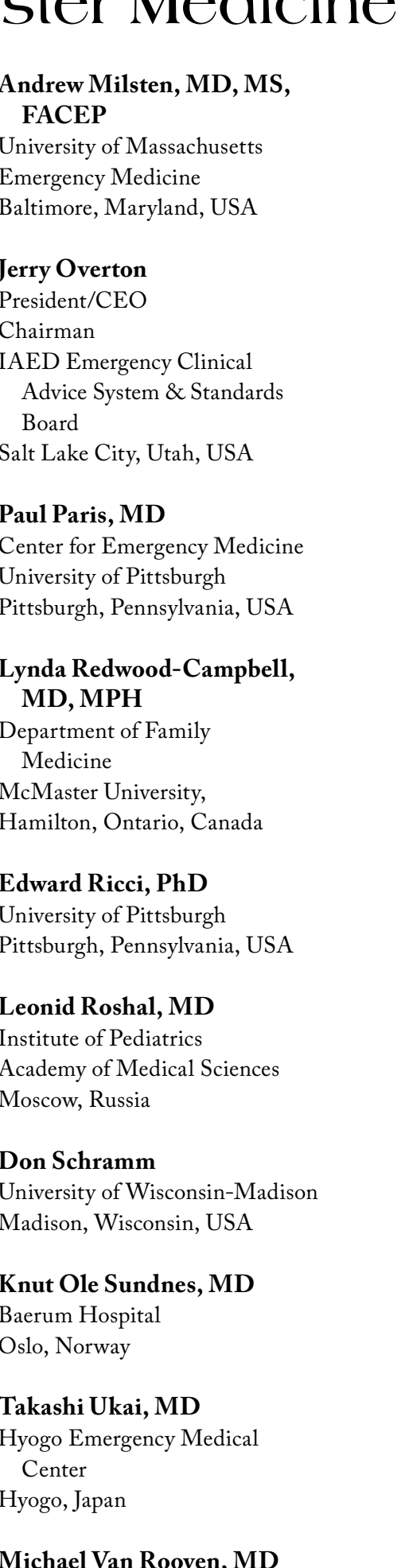

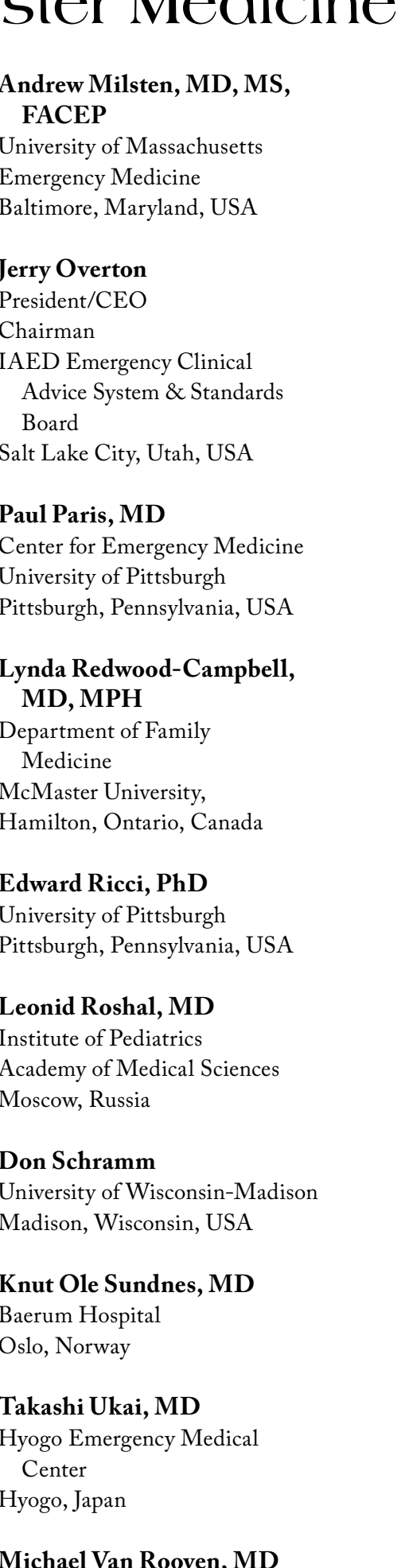

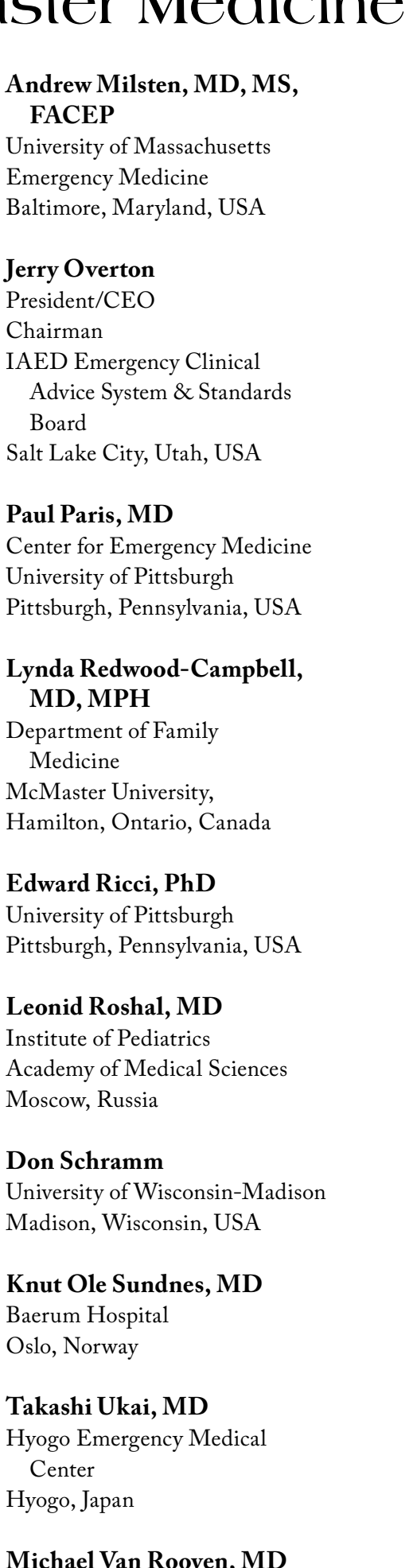

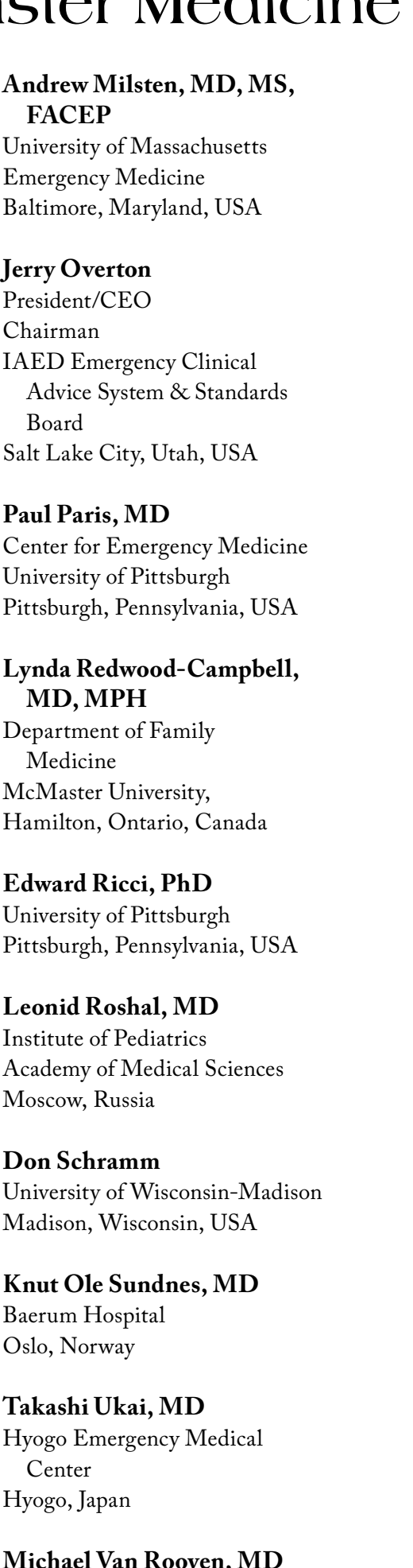

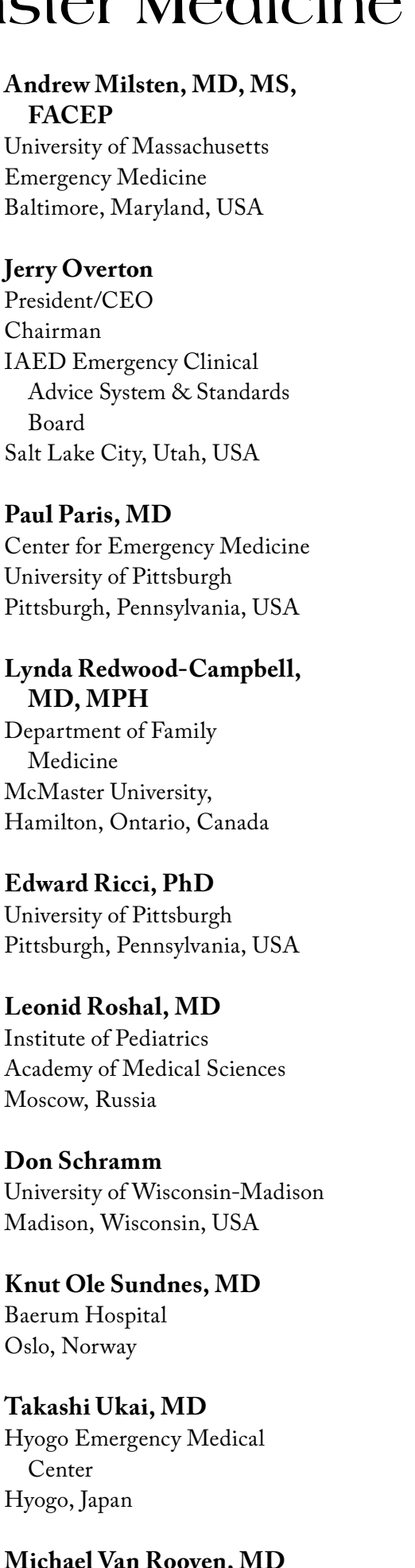

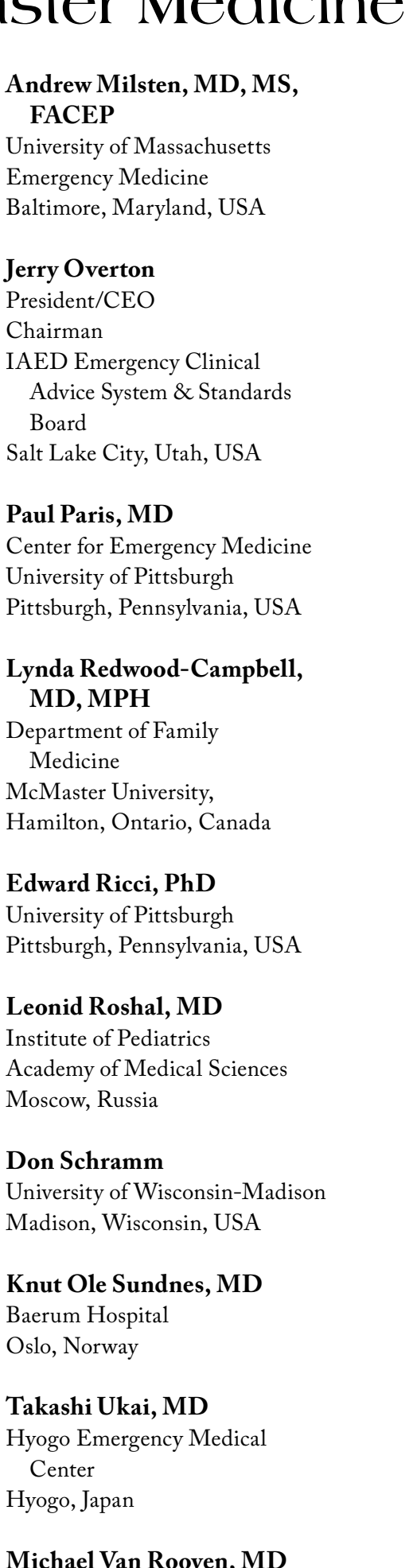

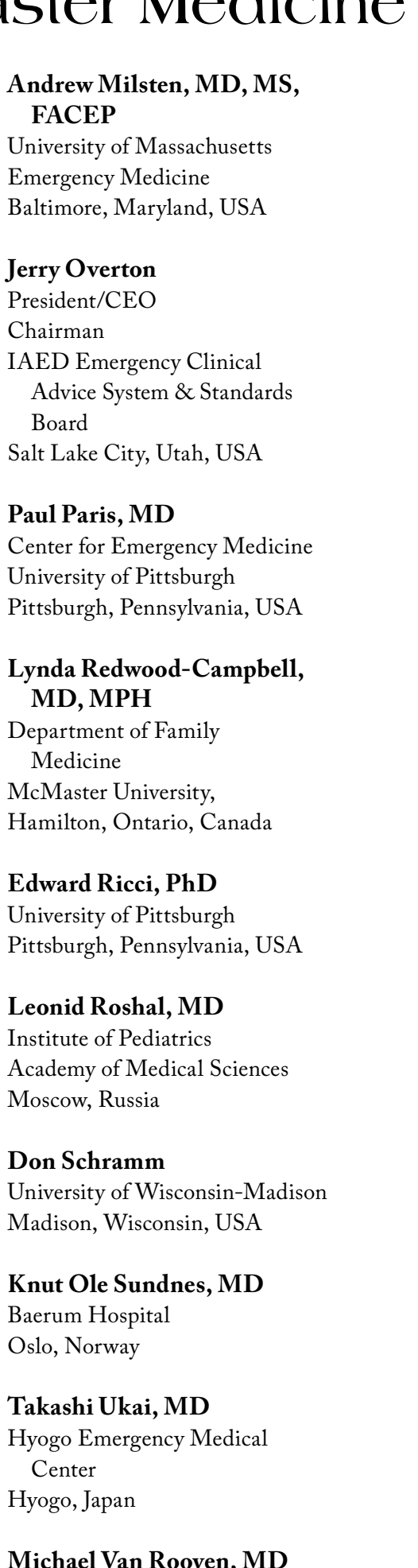

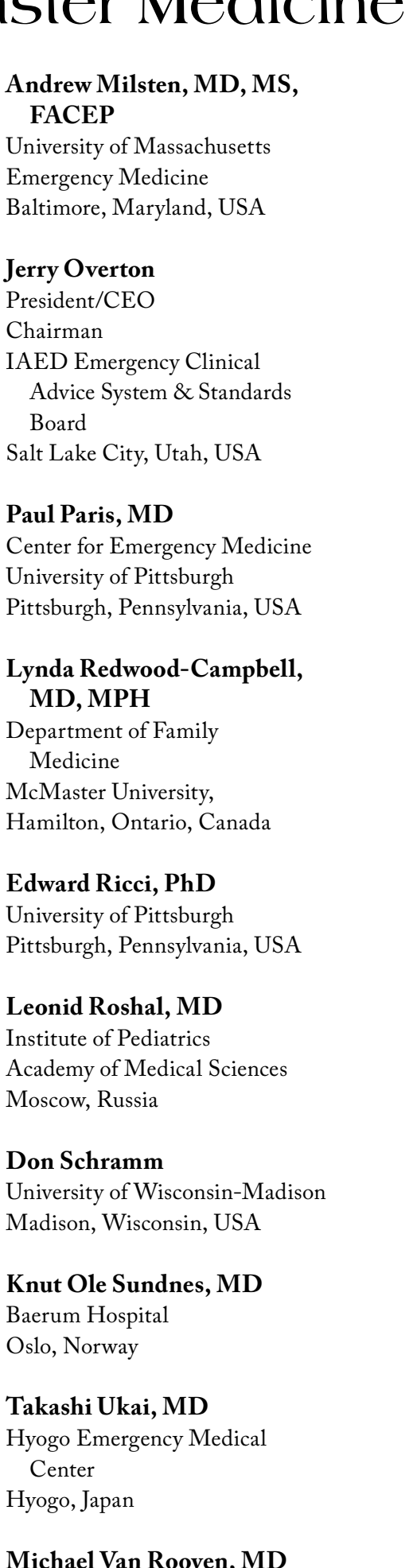

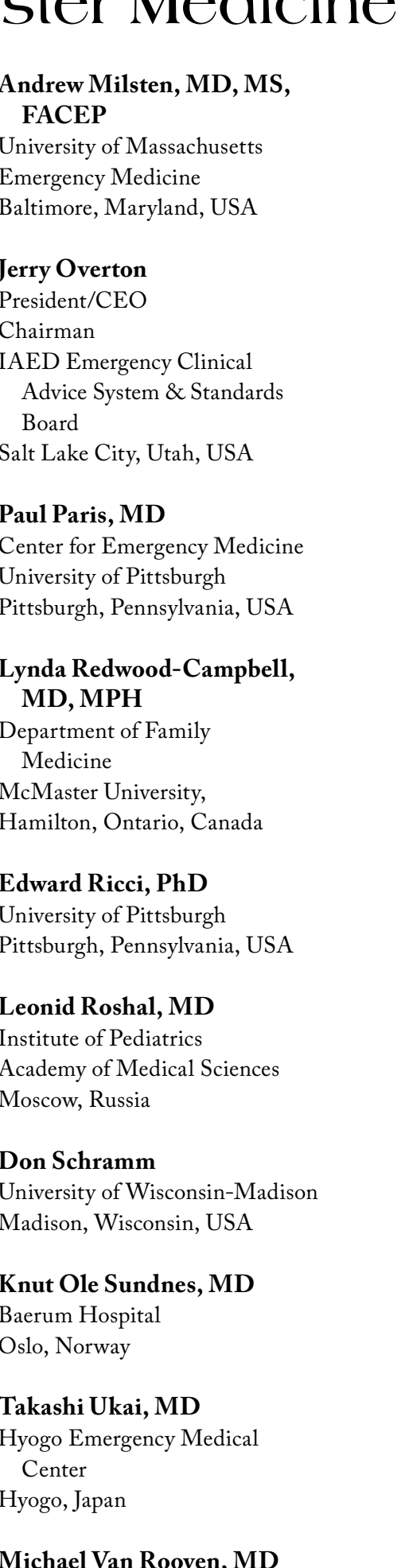

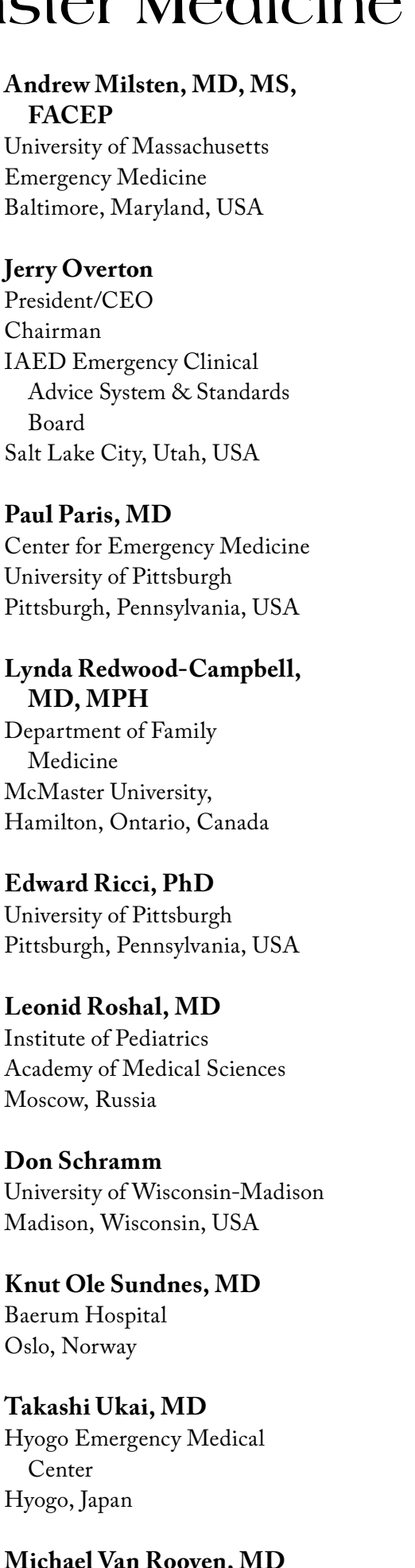

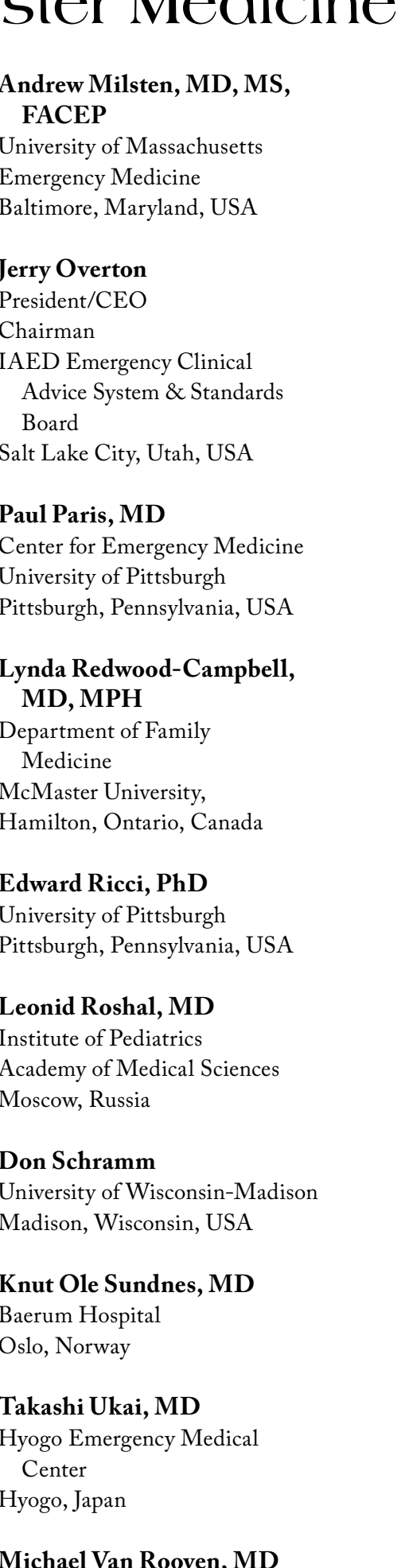

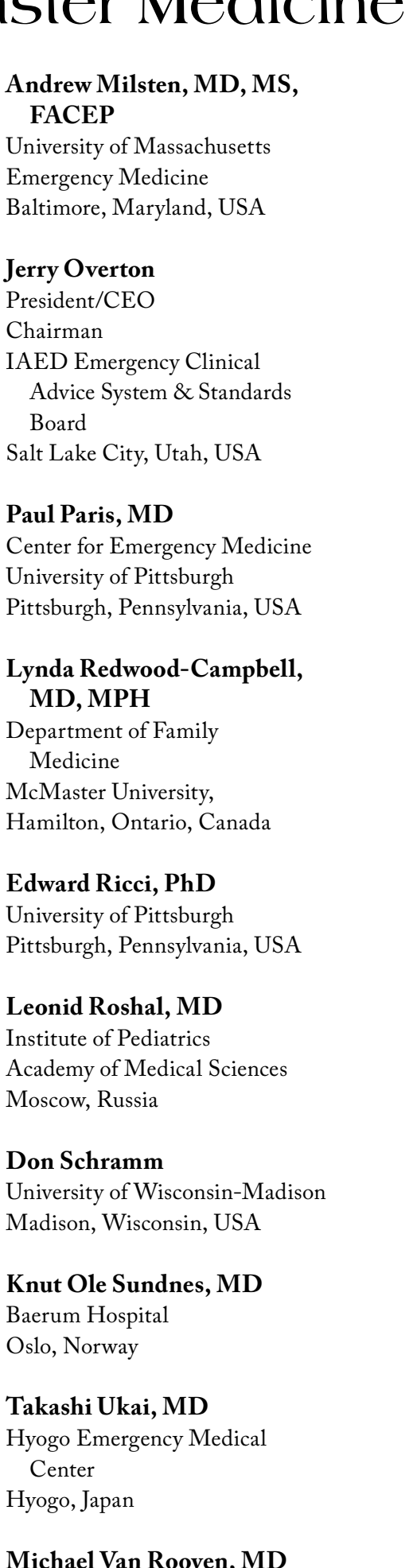

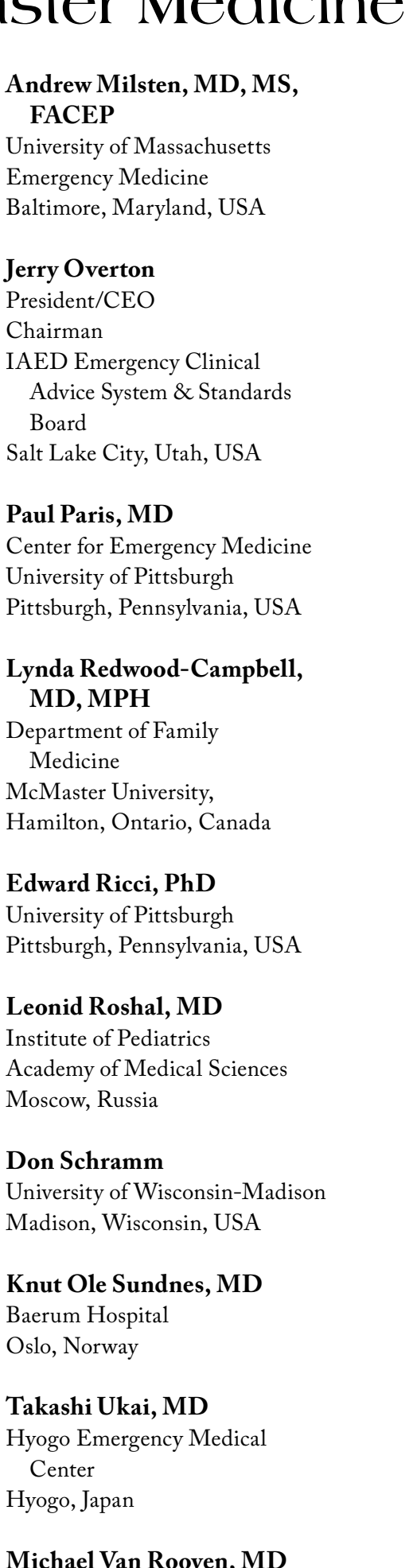

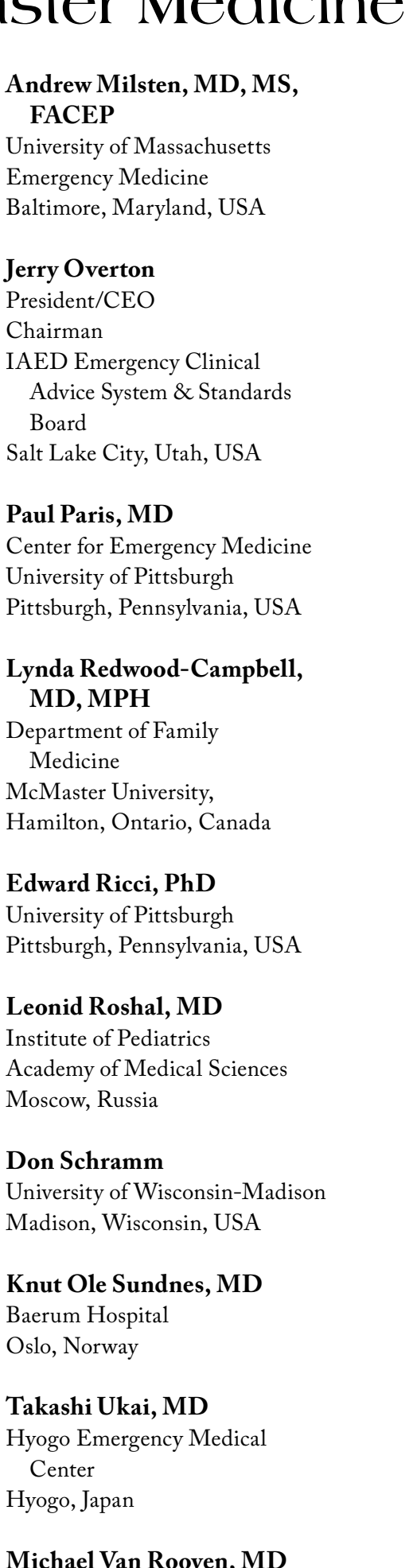

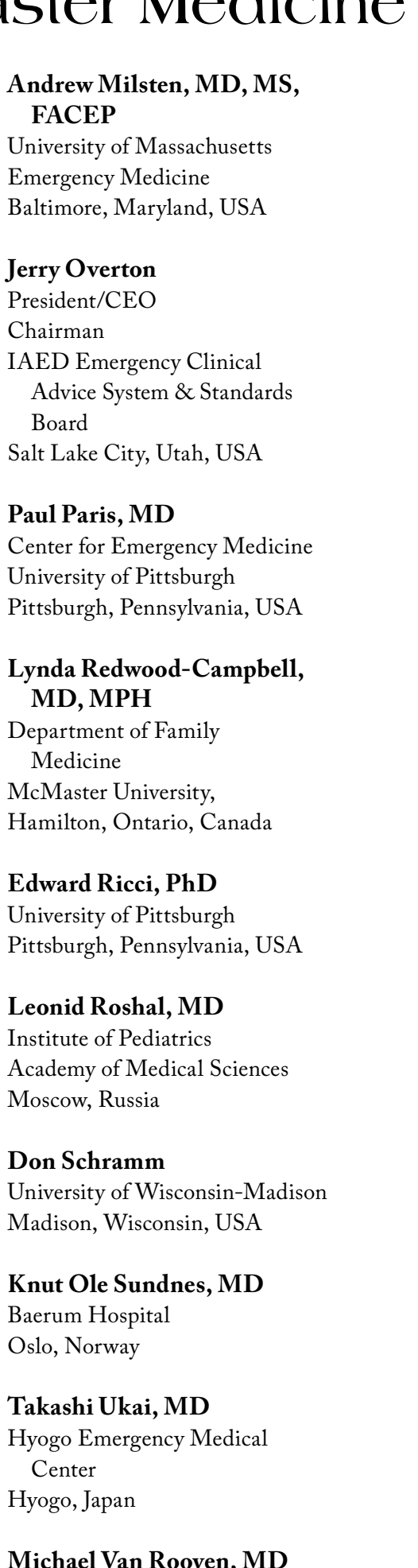

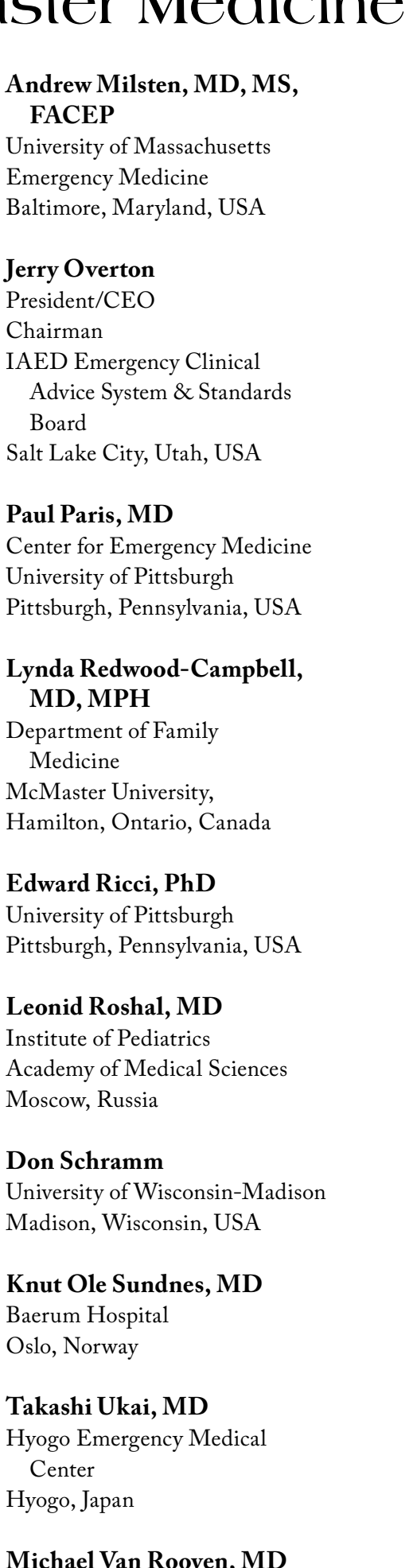

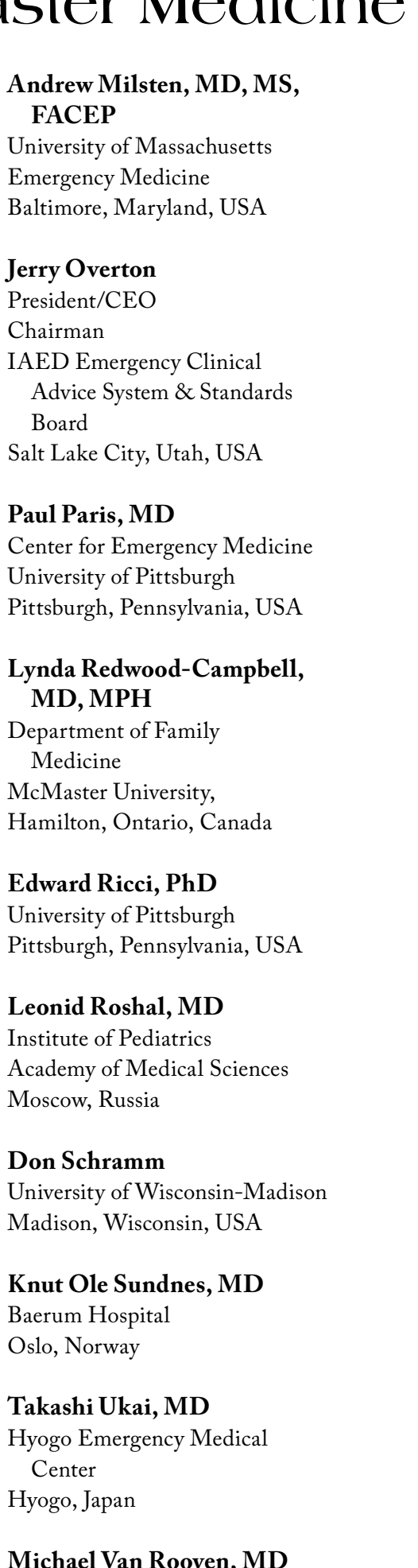

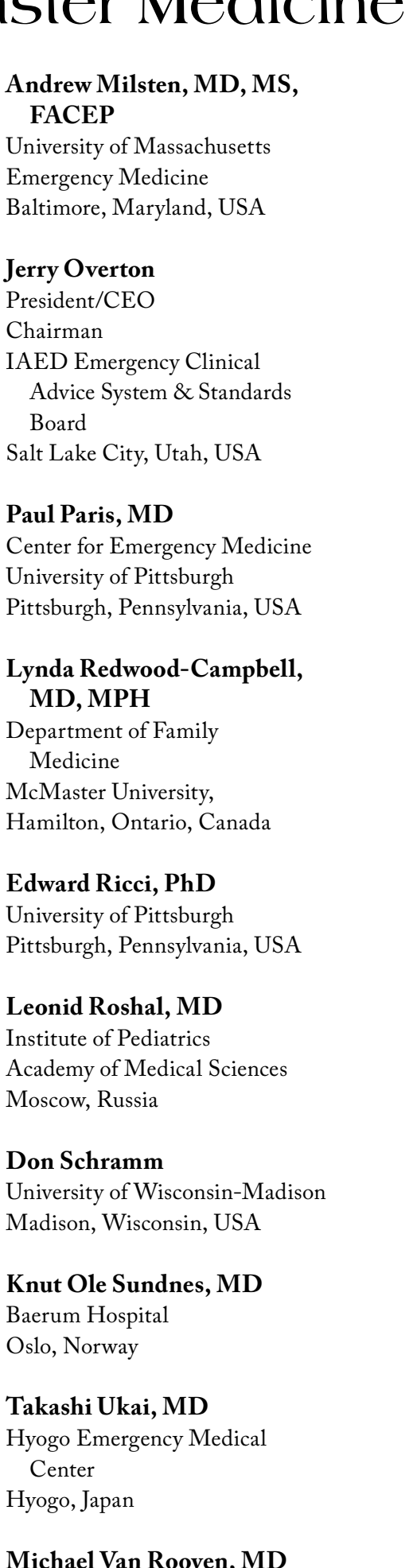

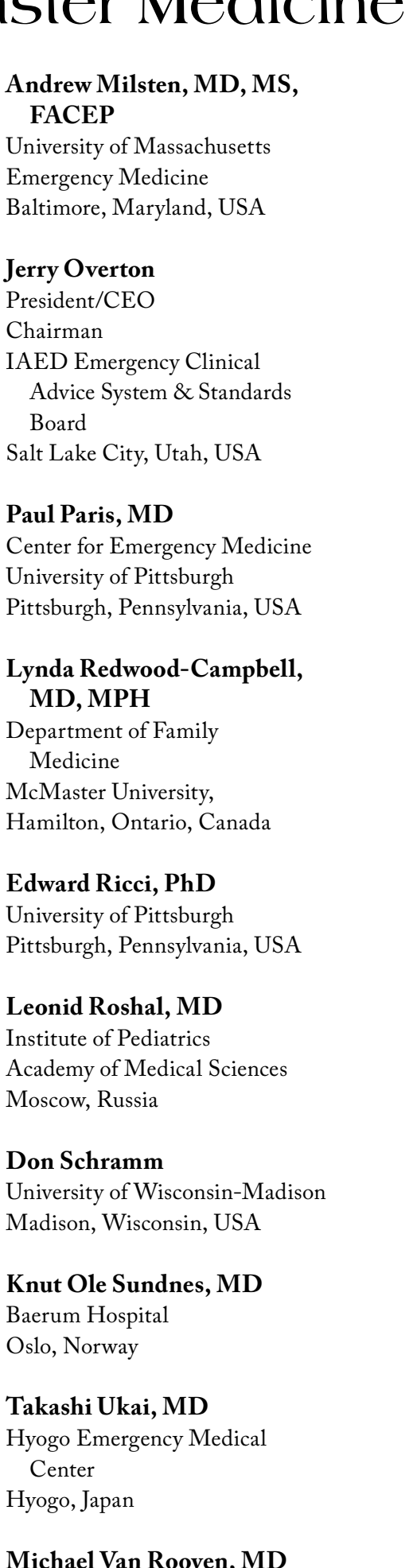

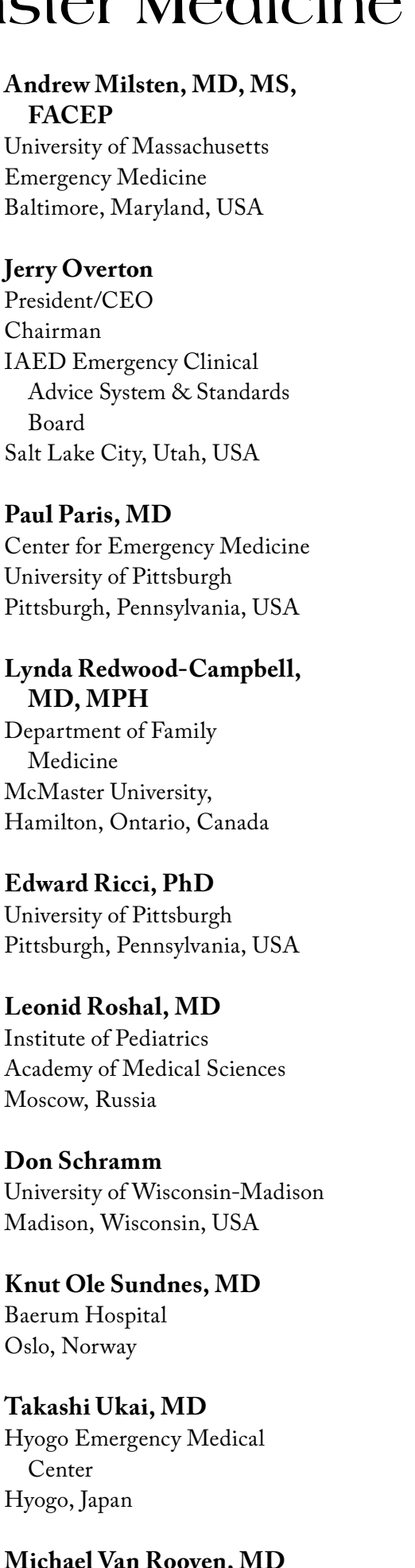

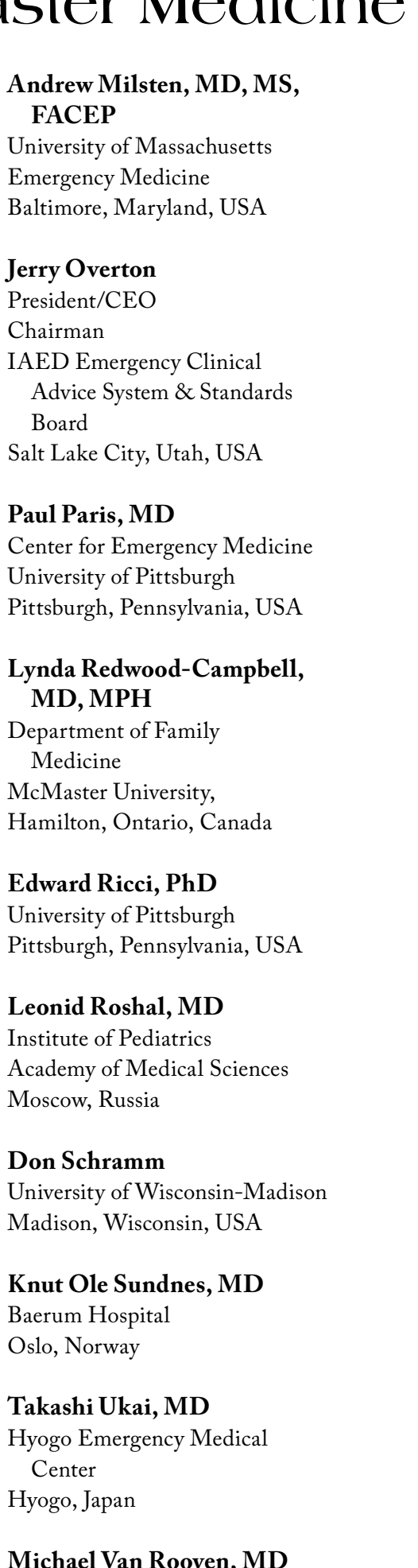

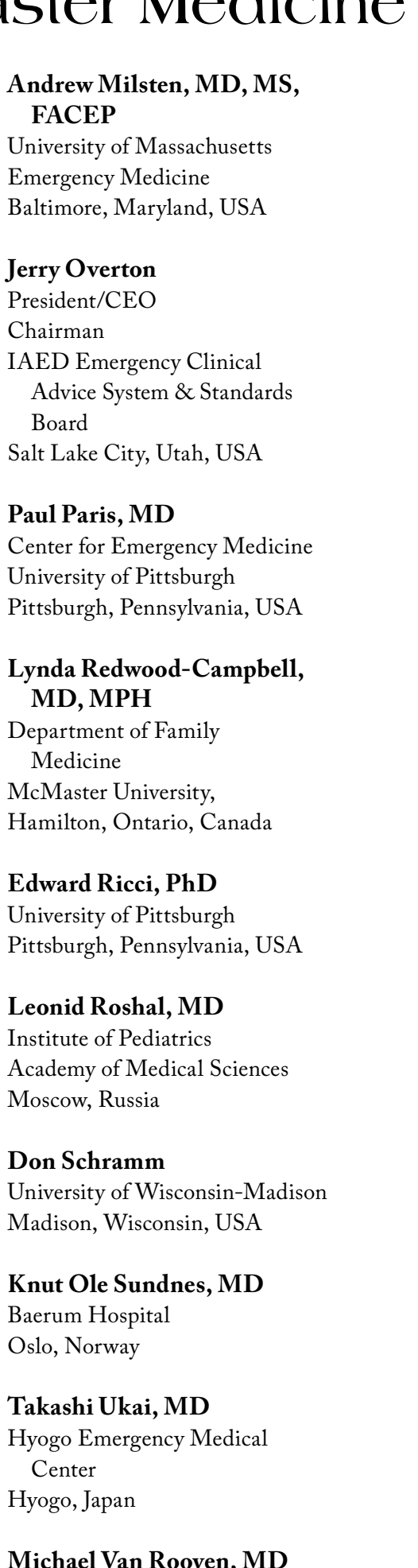

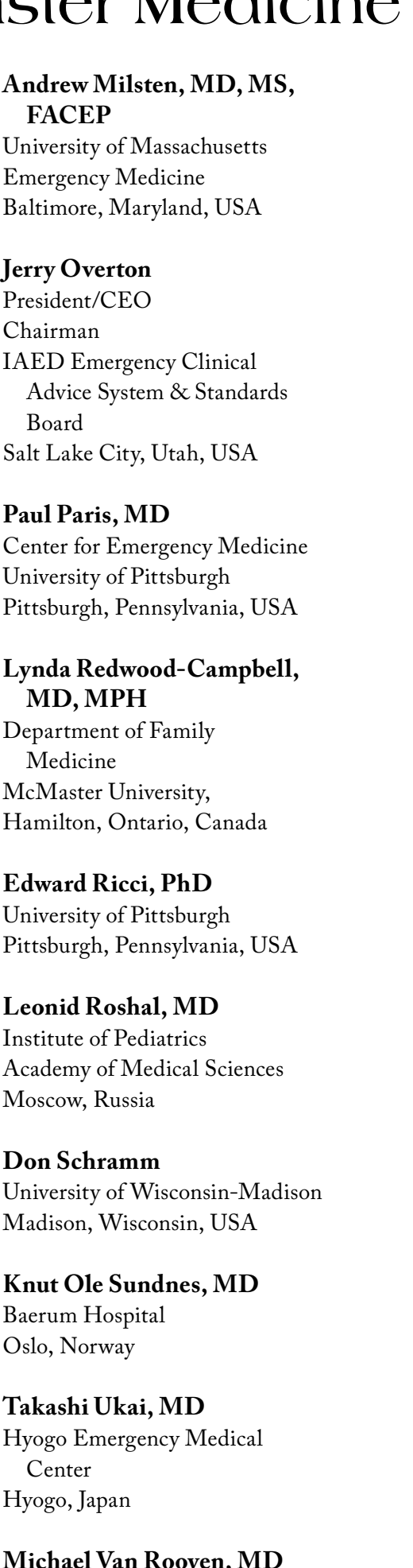

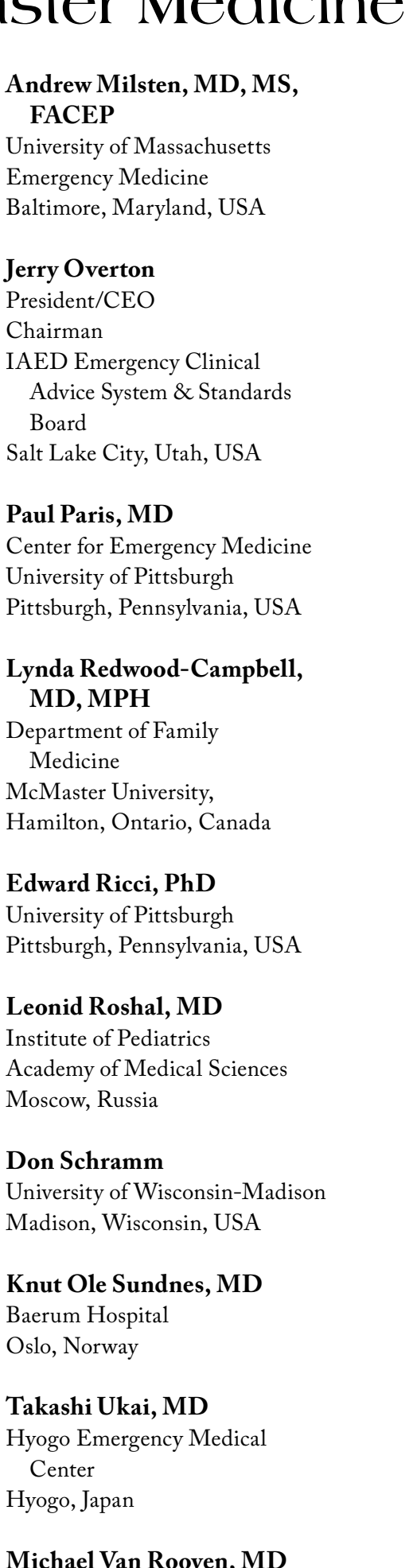

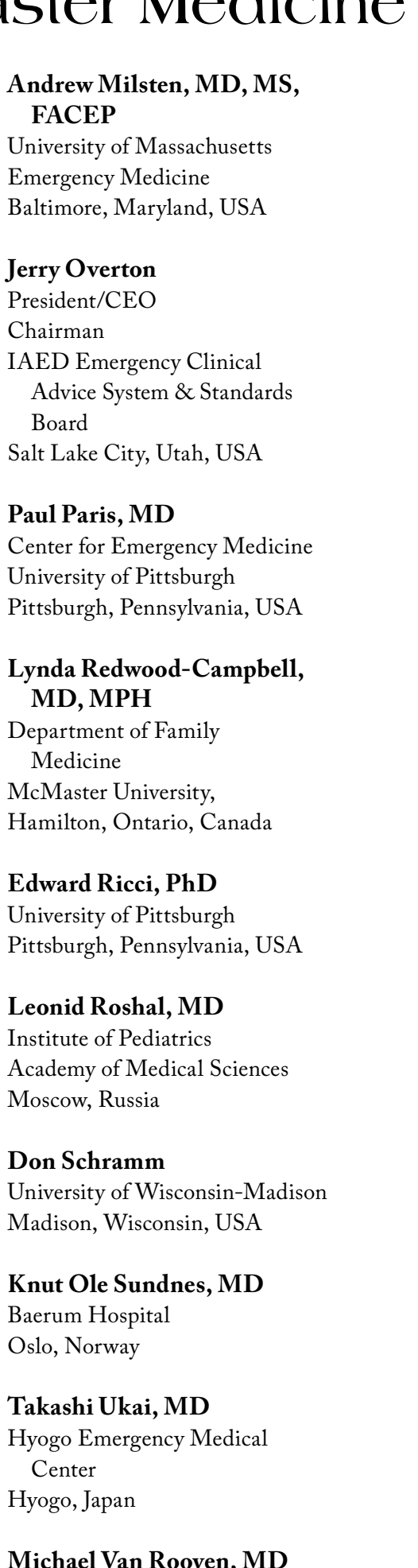

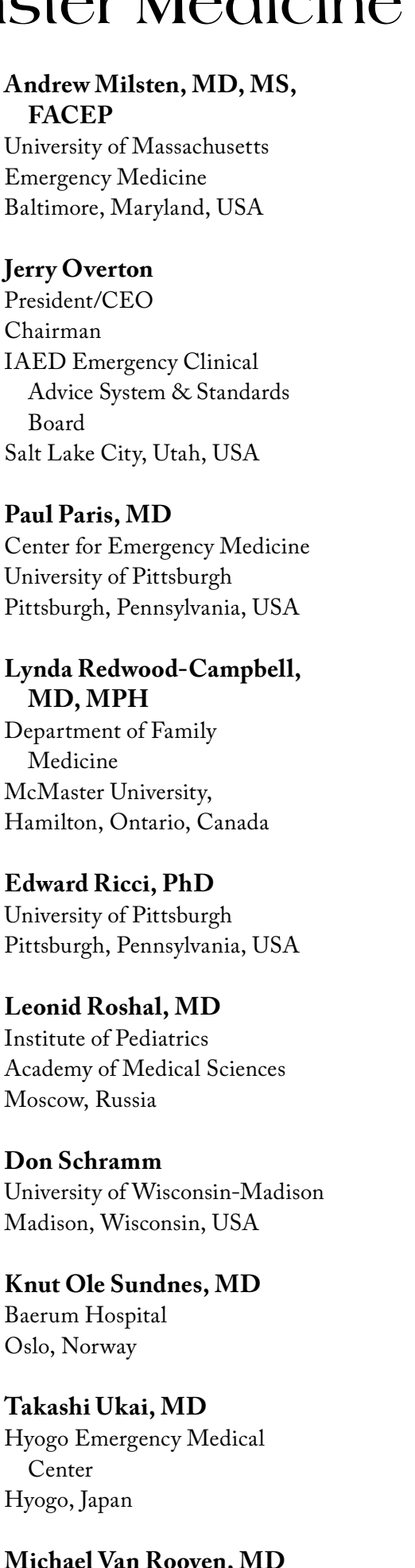

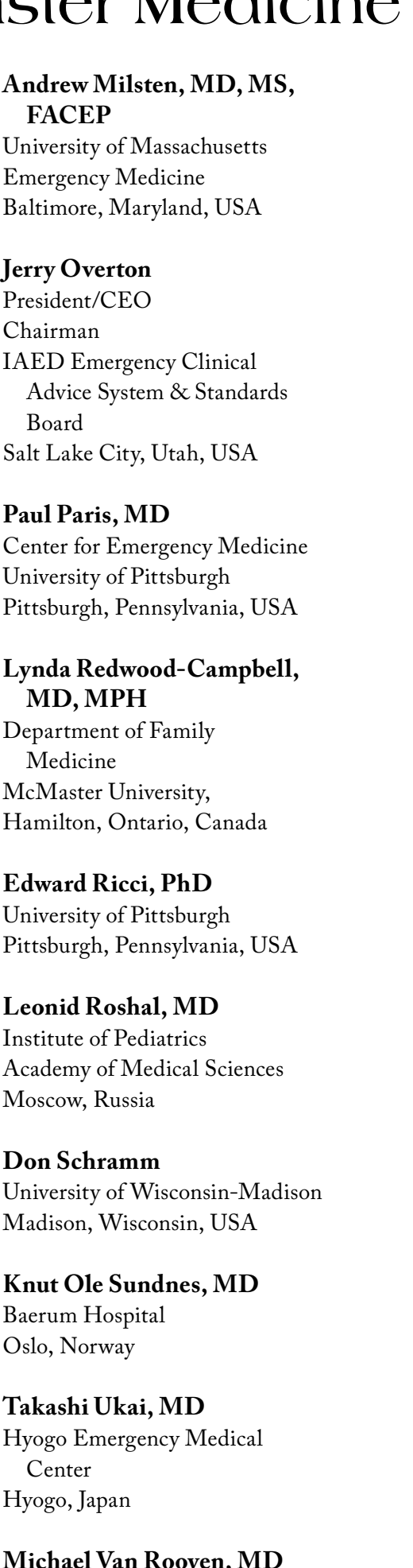

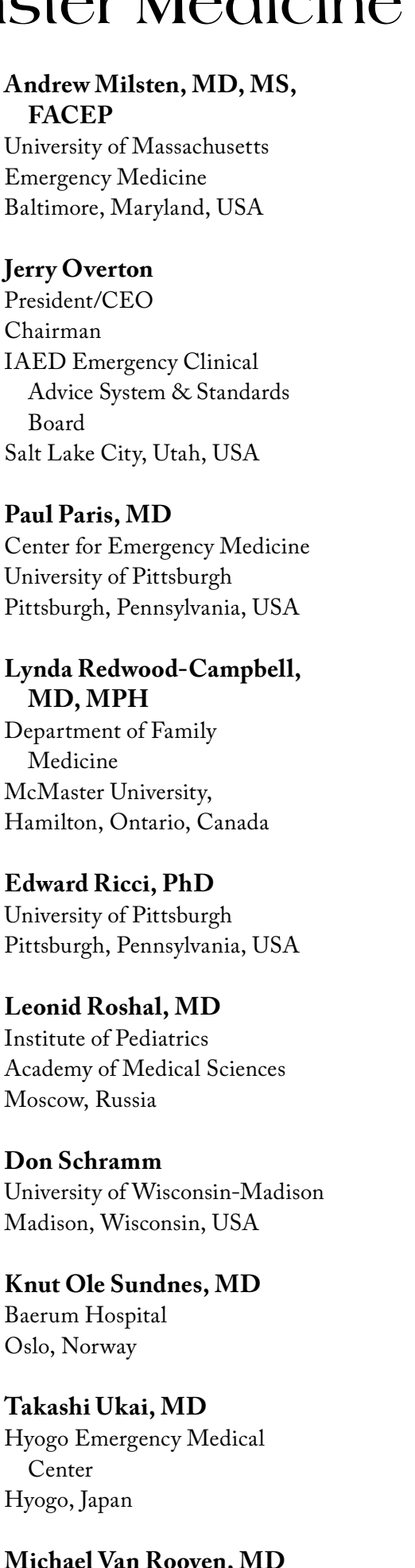

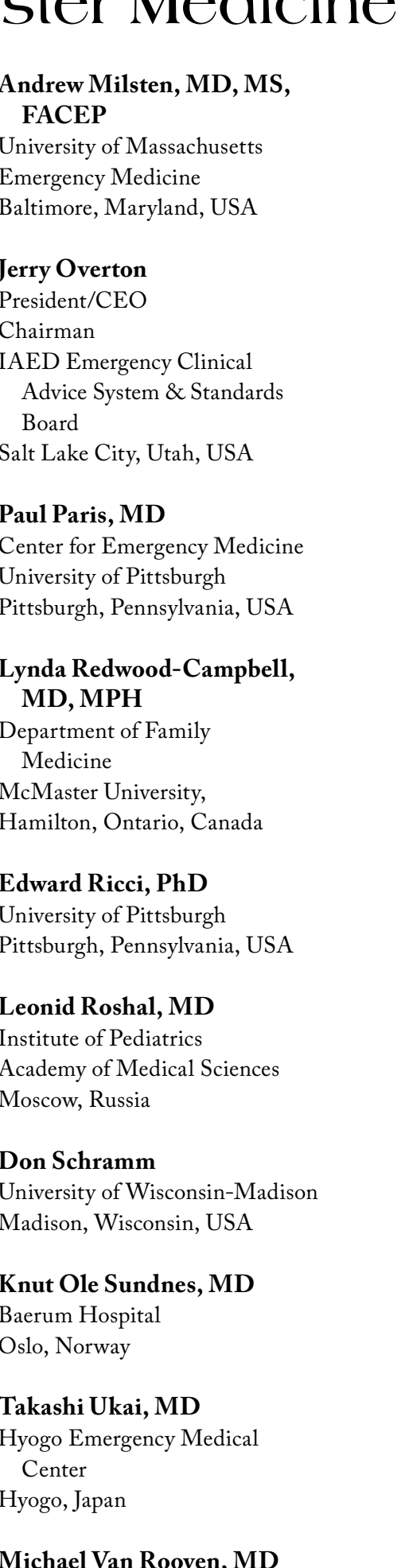

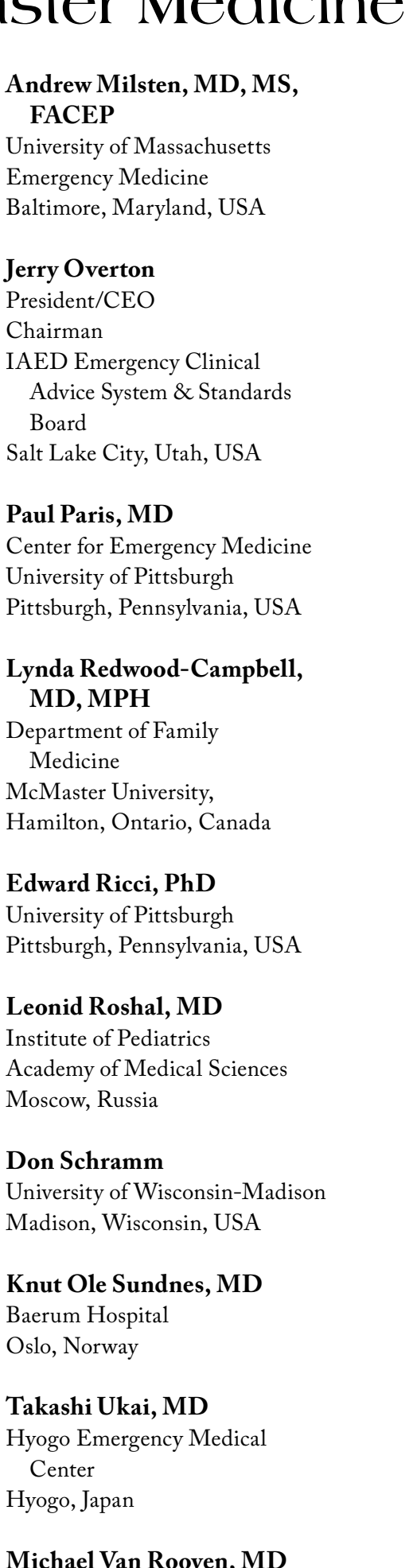

Michael Van Rooyen, MD

Associate Professor, Harvard

Medical School, Brigham and

Women's Hospital

Boston, Massachusetts, USA 
Aims and Scope: The mission of Prehospital and Disaster Medicine (PDM) is the distribution of information relevant to the practice of out-of-hospital and in-hospital emergency medical care, disaster health, and public health and safety. PDM provides an international forum for the reporting and discussion of scientific studies, both quantitative and qualitative, that have relevance to the above practices. The major objectives are: (1) the improvement of the types and quality of the care delivered to patients with perceived medical emergencies and to victims of multi-casualty accidents or disasters, including the public health and safety aspects of such events; and (2) the prevention and/or mitigation of the occurrence of such events and of the effects of these events upon the human population and environment.

Editorial Office: Prehospital and Disaster Medicine, 3330 University Avenue, Suite 130, Madison, Wisconsin 53705, USA. Telephone: (+1) (608) 819-6604; Facsimile (+1) (608) 819-6055; E-mail: pdm@wadem.org

Publishing, Production, and Advertising Office: Cambridge University Press, 32 Avenue of the Americas, New York, NY 10013-2473, United States.

Subscription Offices: (for USA, Canada, and Mexico) Cambridge University Press, 32 Avenue of the Americas, New York, NY 10013-2473, United States; (for UK and elsewhere) Cambridge University Press, The Edinburgh Building, Shaftesbury Road, Cambridge CB2 8RU, UK.

2012 Subscription Information: Prehospital and Disaster Medicine (Print ISSN 1049-023X; Electronic ISSN 1945-1938) is published bimonthly in the months of February, April, June, August, October, and December by Cambridge University Press, 32 Avenue of the Americas, New York, NY 10013-2473, United States/Cambridge University Press, The Edinburgh Building, Shaftesbury Road, Cambridge CB2 8RU, UK for the World Association for Disaster and Emergency Medicine. 2012 Annual subscription rates: Institutions print and electronic: US\$516.00 in the USA, Canada, and Mexico; UK£313.00+VAT elsewhere. Institutions electronic only: US $\$ 375.00$ in the USA, Canada, and Mexico; UK£227.00+VAT elsewhere. Individuals print and electronic: US\$153.00 in the USA, Canada, and Mexico; UK£93.00+VAT elsewhere. Individuals electronic only: US\$113.00 in the USA, Canada, and Mexico; UK£68.50+VAT elsewhere. Single Part: US\$94.00 in the USA, Canada, and Mexico; UK£57.00+VAT elsewhere. Prices include postage and insurance. Airmail or registered mail is extra. Back volume prices are available upon request.

Submissions: All manuscripts must be submitted through the Journal's online submission platform, ScholarOne Manuscripts, at http://mc.manuscriptcentral.com/pdm. Please review the Author Instructions and Author Checklist available online before finalizing a submission.

Indexing: National Library of Medicine (MEDLINE), Cumulative Index to Nursing and Allied Health (CINAHL), and Heath Star Cumulative Index.

(C) World Association for Disaster and Emergency Medicine 2012. All rights reserved. No part of this publication may be reproduced, in any form or by any means, electronic, photocopying, or otherwise, without permission in writing from Cambridge University Press. Policies, request forms, and contacts are available at: http://www.cambridge.org/rights/permissions/permission. $\mathrm{htm}$. Permission to copy (for users in the United States) is available from Copyright Clearance Center Transactional Reporting Service, 222 Rosewood Drive, Danvers, MA 01923, USA. http://www.copyright.com, email: info@ copyright.com.

Printed in United States of America on acid-free paper.

Postmaster: Send address changes in the USA and Canada to Prehospital and Disaster Medicine, Subscription Department, Cambridge University Press, 100 Brook Hill Drive, West Nyack, NY 10994-2133, USA.

Periodical postage rate paid at New York, NY and additional mailing offices. 


\section{CAMbridge}

\section{JOURNALS}

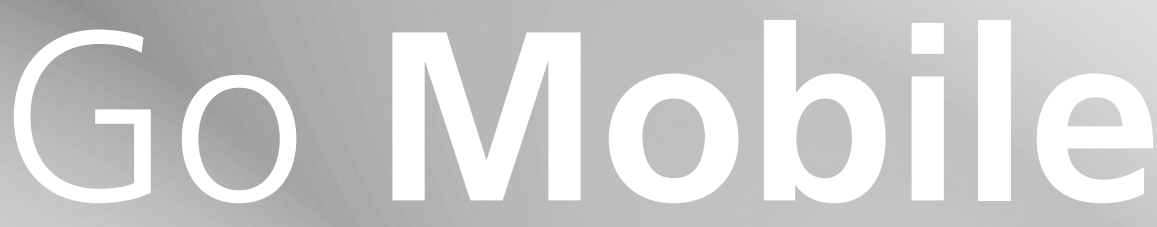

CJO Mobile $(\mathrm{CJOm})$ is a streamlined

Cambridge Journals Online (CJO)

for smartphones and other small mobile devices

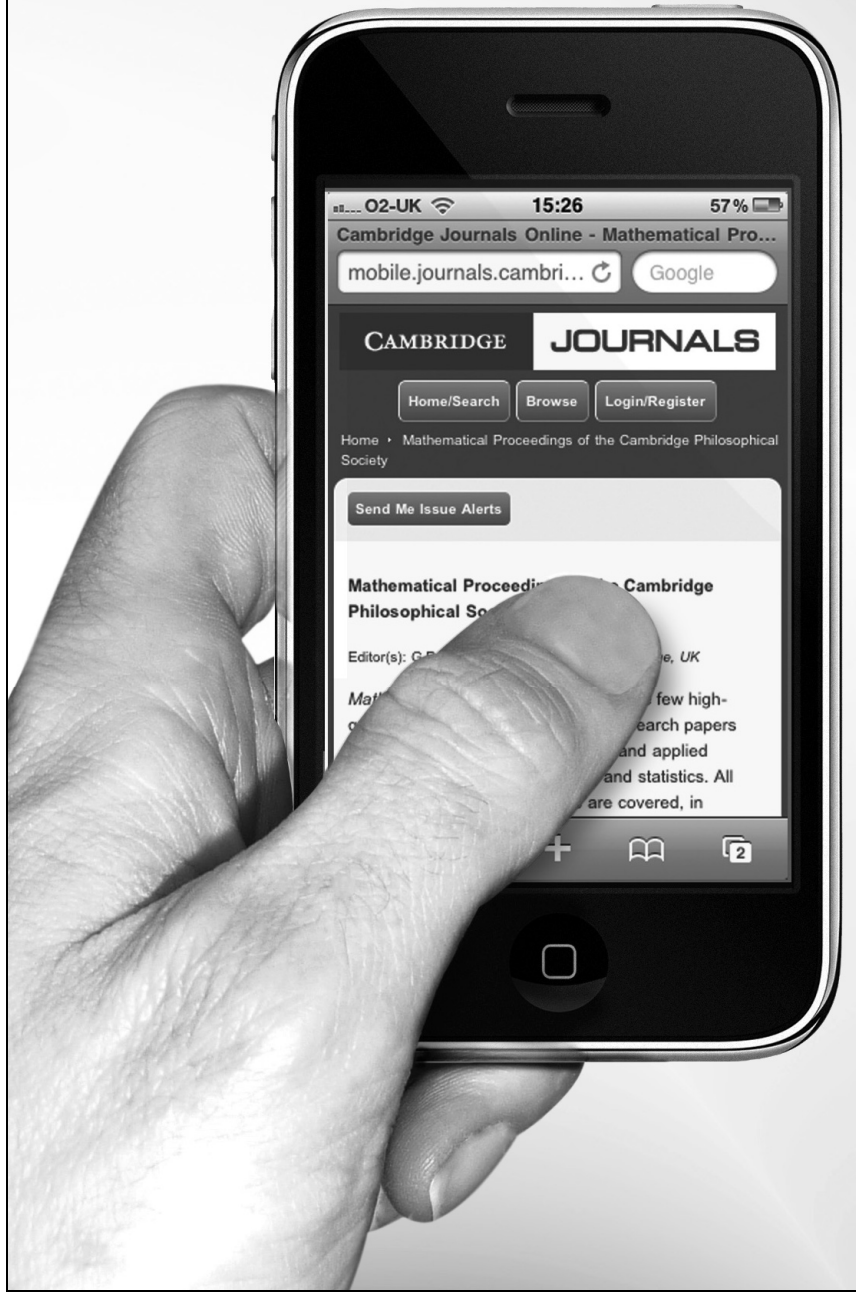

- Use CJOm to access all journal content including FirstView articles which are published online ahead of print

- Access quickly and easily thanks to simplified design and low resolution images

- Register for content alerts or save searches and articles they will be available on both CJO and CJOm

- Your device will be detected and automatically directed to CJOm via: journals.cambridge.org 